THE BEDFORD SERIES IN HISTORY AND CULTURE

\title{
The Movements of the New Left, 1950-1975
}

A Brief History with Documents 
Related Titles in

\section{THE BEDFORD SERIES IN HISTORY AND CULTURE}

Advisory Editors: Lynn Hunt, University of California, Los Angeles

David W. Blight, Yale University

Bonnie G. Smith, Rutgers University

Natalie Zemon Davis, Princeton University

Ernest R. May, Harvard University

Postwar Immigrant America: A Social History

Reed Ueda, Tufts University

Women's Magazines, 1940-1960: Gender Roles and the Popular Press

Edited with an Introduction by Nancy A. Walker, Vanderbilt University

American Cold War Strategy: Interpreting NSC 68

Edited with an Introduction by Ernest R. May, Harvard University

The Age of McCarthyism: A Brief History with Documents, Second Edition

Ellen Schrecker, Yeshiva University

To Secure These Rights: The Report of Harry S Truman's Committee on Civil Rights

Edited with an Introduction by Steven F. Lawson, Rutgers University

American Social Classes in the 1950s: Selections from Vance Packard's The Status SeEKers

Edited with an Introduction by Daniel Horowitz, Smith College

Brown v. Board of Education: A Brief History with Documents

Waldo E. Martin Jr., University of California, Berkeley

Martin Luther King Jr., Malcolm X, and the Civil Rights Struggle of the 1950s and 1960s: A Brief History with Documents

David Howard-Pitney, De Anza College

Lyndon B. Johnson and American Liberalism: A Brief Biography with Documents

Bruce J. Schulman, Boston University

César Chávez: A Brief Biography with Documents

Edited with an Introduction by Richard W. Etulain, University

of New Mexico

My Lai: A Brief History with Documents

James S. Olson, Sam Houston State University, and Randy Roberts,

Purdue University 


\title{
The Movements of the New Left, 1950-1975
}

\section{A Brief History with Documents}

\author{
Van Gosse \\ Franklin and Marshall College
}


For Bedford/St. Martin's

Executive Editor for History: Mary V. Dougherty

Director of Development for History: Jane Knetzger

Developmental Editor: Ann Hofstra Grogg

Editorial Assistant: Carina Schoenberger

Senior Production Supervisor: Dennis J. Conroy

Production Associate: Chris Gross

Senior Marketing Manager: Jenna Bookin Barry

Project Management: Books By Design, Inc.

Text Design: Claire Seng-Niemoeller

Indexer: Books By Design, Inc.

Cover Design: Billy Boardman

Cover Art: Central State University Protesters with Clenched Fists. Columbus, Ohio, May 22, 1969. (C) Bettmann/CORBIS

Composition: Stratford Publishing Services

President: Joan E. Feinberg

Editorial Director: Denise B. Wydra

Director of Marketing: Karen Melton Soeltz

Director of Editing, Design, and Production: Marcia Cohen

Manager, Publishing Services: Emily Berleth

Library of Congress Control Number: 2004107771

Copyright (C) 2005 by Bedford /St. Martin's

Softcover reprint of the hardcover 1st edition 2005 978-1-4039-6804-3

All rights reserved. No part of this book may be reproduced, stored in a retrieval system, or transmitted in any form or by any means, electronic, mechanical, photocopying, recording, or otherwise, except as may be expressly permitted by the applicable copyright statutes or in writing by the Publisher.

$\begin{array}{lll}7 & 6 & 5\end{array}$

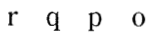

For information, write: Bedford/St. Martin's, 75 Arlington Street, Boston, MA 02116 (617-399-4000)

ISBN 978-1-349-73428-3 ISBN 978-1-137-04781-6 (eBook)

DOI 10.1007/978-1-137-04781-6

\section{Acknowledgments}

Acknowledgments and copyrights appear at the back of the book on pages 190-91, which constitute an extension of the copyright page.

Transferred to Digital Printing 2015 


\section{Foreword}

The Bedford Series in History and Culture is designed so that readers can study the past as historians do.

The historian's first task is finding the evidence. Documents, letters, memoirs, interviews, pictures, movies, novels, or poems can provide facts and clues. Then the historian questions and compares the sources. There is more to do than in a courtroom, for hearsay evidence is welcome, and the historian is usually looking for answers beyond act and motive. Different views of an event may be as important as a single verdict. How a story is told may yield as much information as what it says.

Along the way the historian seeks help from other historians and perhaps from specialists in other disciplines. Finally, it is time to write, to decide on an interpretation and how to arrange the evidence for readers.

Each book in this series contains an important historical document or group of documents, each document a witness from the past and open to interpretation in different ways. The documents are combined with some element of historical narrative - an introduction or a biographical essay, for example - that provides students with an analysis of the primary source material and important background information about the world in which it was produced.

Each book in the series focuses on a specific topic within a specific historical period. Each provides a basis for lively thought and discussion about several aspects of the topic and the historian's role. Each is short enough (and inexpensive enough) to be a reasonable one-week assignment in a college course. Whether as classroom or personal reading, each book in the series provides firsthand experience of the challengeand fun - of discovering, recreating, and interpreting the past.

Lynn Hunt David W. Blight

Bonnie G. Smith Natalie Zemon Davis Ernest R. May 



\section{Preface}

The Movements of the New Left, 1950-1975, is a documentary history of New Left radicalism from its birth in the 1950s through its dispersion and institutionalization in the early 1970s. The book begins with the premise that to understand the multiple social movements of that period we have to recognize them collectively as the New Left. This conception departs from the commonplace definition of the New Left as the white student movement of the 1960s, placed between a civil rights movement beginning in the 1950s and the women's liberation movement cresting in the 1970s. An inclusive definition of the New Left is both more accurate and more useful in introducing students to the complex political dynamics of "the Sixties." Instead of learning about many separate strands of activism, students are encouraged to seek commonalities, to analyze how "the Movement" as a whole changed over time. In particular, I hope this book challenges students to think about the commitment shared by all of these movements to a radical understanding of democracy, and how that resonates in American history.

This book is therefore broad in coverage; no other collection of documents on the Sixties includes such a wide range of groups and individuals. In addition to the Student Nonviolent Coordinating Committee, Tom Hayden, Martin Luther King Jr., Betty Friedan, and Malcolm X, students will explore primary sources from the Mattachine Society, the Congressional Black Caucus, the Young Lords Party, Father Daniel Berrigan, and Congresswoman Bella Abzug. In addition to a wide variety of voices, students will encounter a broad range of source types, including manifestos, testimonies, speeches, newspaper advertisements, letters, and excerpts from books.

The organization of The Movements of the New Left, 1950-1975, combines chronological and thematic approaches. In the introduction to the documents each movement is examined in turn within a periodization of successive phases: first, the transition from the 1940s to 
the cold war era, when the first hints of a new radicalism appeared; second, the dramatic upsurge in 1960-65, as the civil rights movement peaked, creating space for other movements; third, the confrontation with cold war liberalism in 1965-68, led by the antiwar movement; finally, the culminating phase during Nixon's presidency, when many new movements emerged, and the larger Left dispersed.

The introduction is followed by forty-five documents, representing all parts of the New Left over a quarter century, from the earliest stirring of gay rights activism in 1950 through the consolidation of feminism and Black Power in the 1970s. Each document is introduced by a headnote that situates it historically and provides key information about its author. Footnotes clarify topical references within each document. The documents are followed by a chronology to help students trace the chain of causality between major events and various movements, questions for consideration to aid class discussion, and a selective bibliography for students who wish to pursue research on a particular movement or individual. Finally, the index lists all common acronyms - such as SNCC and SDS-for easy reference.

\section{ACKNOWLEDGMENTS}

I have incurred many debts in the nearly ten years it took to complete this book, from Charles Christensen, who originally signed it for the Bedford series in 1995, to Patricia Rossi, who oversaw its completion. I am grateful to both for encouraging the breadth of this work, and especially grateful to Patricia Rossi for her commitment to seeking out the best historical scholarship. At Bedford, I have benefited from the guidance of Ann Hofstra Grogg and Jane Knetzger. Their professionalism saved me from making many errors.

Among many helpful colleagues, I want to thank several who made documents available or read individual chapters. Max Elbaum shared with me his encyclopedic knowledge of the late sixties and the New Communist Movement. Lise Vogel encouraged me to rethink the conventional narrative of women's liberation. James Miller improved my understanding of Black Power, and is always a good friend. Jeffrey Escoffier pointed me at the right books to read on gay liberation. I owe a special debt to Ellen Schrecker, Yeshiva University, who originally inspired me to propose a Bedford book and has critiqued several versions of this manuscript. She and Nancy MacLean, Northwestern University; Robert O. Self, University of Wisconsin, Milwaukee; R. War- 
ren Metcalf, University of Oklahoma; Peter B. Levy, York College; and John D'Emilio, University of Illinois at Chicago, were among the final group of readers who gave it a close reading and made it much better thereby. I thank all.

This book is dedicated to a fellow activist and historian, Johanna O'Mahony Gosse, and to her wonderful mother and fellow historian, Eliza Jane Reilly. They are my best teachers.

Van Gosse 



\section{Contents}

Foreword $\mathrm{v}$

Preface vii

\section{PART ONE}

Introduction: A Movement of Movements 1

Seeds of Dissent in the 1940s and 1950s 4

The Movements Take Off, 1960-1965 7

The Cold War Consensus Cracks, 1965-1968 16

High Tide and Ebb Tide, 1969-1975 23

Conclusion: The Movements Go Their Own Way 35

\section{PART TWO}

The Documents 39

1. Mattachine Society, Statement of Purpose, 1951

2. Coleman Young, Testimony Before the House Committee on Un-American Activities, February 28, 1952

3. Jo Ann Robinson, Letter to Mayor W. A. Gayle, May 21, 1954 
4. Rosa Parks, The Montgomery Bus Boycott:

Talk at the Highlander Folk School, March 1956

5. Liberation, Tract for the Times: Editorial, March 1956

6. Committee for a Sane Nuclear Policy, We Are Facing a Danger Unlike Any Danger That Has Ever Existed:

Advertisement in the New York Times, November 15, 195752

7. Student Nonviolent Coordinating Committee, Statement of Purpose, May 14, 1960

8. Fair Play for Cuba Committee, Cuba: A Declaration of Conscience by Afro-Americans: Advertisement in the New York Post, April 25, 1961

9. Dale Johnson, On the Ideology of the Campus Revolution, May 1961

10. Fannie Lou Hamer, Remembering 1962, 1977

11. Tom Hayden and Students for a Democratic Society, The Port Huron Statement, August 1962

12. Betty Friedan, The Feminine Mystique, 1963

13. Martin Luther King Jr., Letter from Birmingham Jail, April 16, 1963

14. John Lewis, Wake Up America! August 28, 1963

15. Malcolm X, Message to the Grassroots,

November 10, 1963

16. Civil Rights Act of 1964, Title VII, July 2, 1964

17. Sally Belfrage, Remembering Freedom Summer, 1965

18. Mario Savio, An End to History, November 1964

19. Lyndon B. Johnson, The American Promise:

Special Message to the Congress, March 15, 1965

20. Paul Potter, The Incredible War, April 17, 1965

21. Casey Hayden and Mary King, Sex and Caste, November 18, 1965

22. Black Panther Party for Self-Defense, The Ten-Point Program: What We Want/What We Believe, October 1966103

23. National Organization for Women, Statement of Purpose, October 29, 1966 
24. Stokely Carmichael and Charles V. Hamilton, Black Power, 1967

25. Maulana Karenga, Nguzo Saba: The Seven Principles, 1967111

26. The Resistance, We Refuse - October 16, 1967

27. Martin Luther King Jr., Declaration of Independence from the War in Vietnam, April 4, 1967

28. Daniel Berrigan, Night Flight to Hanoi, 1968

29. New York Radical Women, Principles, 1968

30. New York Radical Women, No More Miss America! August 1968

31. Third World Liberation Front, The Politics of the Strike, 1968

32. Mike Klonsky, Toward a Revolutionary Youth Movement, December 23, 1968

33. Third World Women's Alliance, Equal to What? 1969

34. Young Lords Party, Thirteen Point Program and Platform, 1969

35. Martha Shelley, Gay Is Good, 1969

36. Movimiento Estudiantil Chicano de Aztlán, El Plan de Santa Barbara, April 1969

37. Indians of All Tribes, Proclamation, November 1969

38. Gay Activists Alliance, Preamble to Constitution, December 1969

39. American Civil Liberties Union, On the Record of Police Actions against the Black Panther Party: Press Release, December 29, 1969

40. Kathie Sarachild, Outline for Consciousness-Raising, 1970

41. Tom Grace, Remembering the Killings at Kent State, $1987 \quad 156$

42. Bella Abzug, Testimony Before the New York City Human Rights Commission, September 1970

43. John Kerry, Vietnam Veterans Against the War Testimony to the U.S. Senate Foreign Relations Committee, April 22, 1971 
44. Charles Diggs Jr., Speech at the Congressional Black Caucus Dinner, June 18, 1971

45. Boston Women's Health Book Collective, Our Bodies, Ourselves, 1973

\section{APPENDIXES}

A Chronology of Key Events in the History of the New Left (1949-1975) 175

Questions for Consideration 181

Selected Bibliography 183

Index 193 
THE BEDFORD SERIES IN HISTORY AND CULTURE

\section{The Movements \\ of the New Left, 1950-1975}

A Brief History with Documents 